\title{
Regrowth in post-fire area in a fragment of semideciduous seasonal forest in Viçosa-MG
}

\section{Rebrota em área pós-fogo em um fragmento de floresta estacional semidecidual no município de Viçosa-MG}

\author{
Patrícia Aparecida de Souzaㄹ; Luís Alfredo Pinheiro Leal Nunes²; Gustavo Luna Peixoto³; \\ Sebastião Venâncio Martins ${ }^{4}$ \\ ${ }^{1}$ Engenheira Florestal, Universidade Federal de Tocantins, Doutora em Ciência Florestal, \\ patriciaapsouza@yahoo.com.br \\ 2 Autor para correspondência, Engenheiro Agrônomo, Universidade Federal do Piauí, Doutor em Solos e Nutrição de \\ Plantas, Universidade Federal do Piauí. Departamento de Engenharia Agrícola e Solos, Campus Ministro Petrônio \\ Portela, Bairro Ininga, Teresina-PI, CEP: 64049-550, luisalfredo@ufpi.edu.br \\ ${ }^{3}$ Engenheiro Florestal, Instituto Chico Mendes de Conservação da Biodiversidade, Mestre em Ciência Florestal, \\ glpeixoto@terra.com.br \\ ${ }^{4}$ Engenheiro Florestal, Universidade Federal de Viçosa, Doutor em Botânica, venancio@ufv.br
}

Recebido em: 29-05-2014; Aceito em: 11-06-2015

\begin{abstract}
The sprouting is the typical response of pointers to death of trees as a result of fire, courts, diseases or physiological disorders. The present work aimed to study the regrowth ability of species remaining trees in a Seasonal Forest Semidecidual degraded by fire and assess the importance of resprouting ability in the area of recovery. The fire resulted in the destruction of 12 hectares of native vegetation, with differential levels of degradation. The study focused on the section where the effect of the fire was more severe, with total destruction of the vegetation cover. The area a complete survey of all species showing budding was performed. The diameter $(\mathrm{cm})$ at the base of the bud, using a caliper, and the height $(\mathrm{m})$ of the sprout with the aid of a tape was measured. It was observed that the sprouting capacity varies with the tree species and the size/age of the plant. Mabea fistulifera and Dalbergia nigra showed a higher number of shoots; Anadenanthera macrocarpa and Piptadenia gonoacantha the greatest height and diameter, the first of which also had the highest number of shoots per array; Aegiphila sellowiana showed high potential for regrowth both the stem and the roots. The widespread occurrence of grasses, especially the grass (Melinis minutiflora) represents a physical impediment and reduces the brightness to the by sprouting roots.
\end{abstract}

Additional keywords: budding; forest fire; natural regeneration; secondary succession.

\section{Resumo}

A brotação é a resposta típica à morte de ponteiros de árvores como um resultado de incêndios, cortes, doenças ou distúrbios fisiológicos. O presente trabalho teve como objetivo estudar a capacidade de rebrota de espécies de árvores remanescentes em uma Floresta Estacional Semidecidual degradada pelo fogo e avaliar a importância desta rebrota na capacidade de recuperação da área. $\mathrm{O}$ incêndio culminou com a destruição de 12 hectares da vegetação nativa, apresentando níveis diferenciais de degradação. $O$ estudo concentrou-se no trecho onde o efeito do fogo foi mais severo, com destruição total da cobertura vegetal. $\mathrm{Na}$ área foi realizado um levantamento completo de todas as espécies que apresentaram brotação. Foi medido o diâmetro $(\mathrm{cm})$ na base do broto, utilizando-se um paquímetro, e a altura $(\mathrm{m})$ do broto, com o auxílio de uma trena. Observou-se que a capacidade de rebrota varia com a espécie arbórea e o tamanho/idade da planta. Mabea fistulifera e Dalbergia nigra apresentaram maior número de brotos; Anadenanthera macrocarpa e Piptadenia gonoacantha as maiores altura e diâmetro, sendo que a primeira apresentou, também, o maior número de brotos por matriz; Aegiphila sellowiana apresentou alto potencial de rebrota tanto pelo caule como pelas raízes. A ocorrência generalizada de gramíneas, principalmente do capim-gordura (Melinis minutiflora) representa um impedimento físico e reduz a luminosidade para as brotações por raízes.

Palavras-chave adicionais: brotamento; incêndio florestal; regeneração natural; sucessão secundária.

\section{Introduction}

Fire can change the structure, the floristic composition and the growth of plants, limiting the recruitment of new species and, thus, resulting in lower tree density (Woods, 1989; Cochrane \& Schulze,
1999). The recovery of vegetation after fire can vary depending on the intensity and duration of the fire (Keeley et al., 2003). In some cases, the fire can inhibit the forest regeneration cycle (Kennard et al., 2002; Laurance, 2003; Otterstrom \& Schwartz, 2006). On the other hand, when these disturbances occur in 
intermediate intensity, it may be important for maintaining a large number of species (Hubbell et al., 1999) and rapid regrowth after fire (Hoffmann \& Solbrig, 2003).

However, the fire promotes a reversal of communities to early successional states, in which species previously excluded by competition settle again, and when very aggressive, they may intensify the competition for resources and, following an inhibition model, delay the regeneration process (Sheil \& Burslem, 2003). Some research in Seasonal Semideciduous Forests concluded that the regeneration of this ecosystem hit by the fire is hampered by the occurrence of lianas and that this formation has considerable number of species with regrowth capacity (Silva et al., 2005; Rodrigues et al., 2004; Martins et al., 2002; Penha et al., 2002; Hayashi et al, 2001).

The regrowth process is an alternative to species of several successional groups to reoccupy sites more quickly after a natural or anthropogenic disturbance event, like fire. The sprouting is the typical response to the death of tree pointers as a result of fire, cutting, diseases or physiological disorders (Kramer \& Kozlowski, 1972), where occurs the emission of shoots by resistant buds located in the roots, stem or canopies (Coutinho, 1990).

The regrowth is a regeneration strategy and occurred in $50 \%$ of the species in areas degraded by fire in Semideciduous Forest in Paraguay (Kammesheidt, 1999). The production of shoots depends on the use of nutrients stored in the stumps, assuming that the number and size of sprouts are related to the amount of stored photoassimilates and that the loss of apical dominance induces formation of sprouting in the buds, stimulated by auxins (Kramer \& Kozlowski, 1972).

The growth rate of the shoots, in its early stage of growth, is high in relation to the growth of plants from seedlings. Sharma (1979) noted maximum annual average increment for shoots of Eucalyptus hybrid at 5 and 6 years, to two different sites, while in the first rotation that maximum was reached at 8 and 11 years, respectively. The storage of reserves (organic and inorganic) in lignotubers or in the root system is considered the main reason for this rapid initial growth of shoots. It should also be considered the existence of a root system already formed that favors the absorption of water and nutrients, due to the high proportion of root biomass in relation to shoot. Thus, the regrowth from bud roots in tropical forest environments can be considered as a process that would act on the dynamics of regeneration of these formations (Rodrigues et al., 2005; Greig, 1993; Uhl et al., 1981).

This study aimed to study the regrowth capacity of species of remaining trees in a Seasonal Semideciduous Forest degraded by fire and to assess the importance of this regrowth in the resilience of the area.

\section{Material and methods}

The study was conducted in an area of secondary Seasonal Semideciduous Forest, located on the Campus of the Federal University of Viçosa, in the municipality of Viçosa-MG, $\left(42^{\circ} 53^{\prime} \mathrm{W}\right.$ and $20^{\circ} 45^{\prime}$ $\mathrm{S})$. The climate in the region, according to Köppen classification, is of the Cwb type, tropical of altitude, with hot and rainy summers and cold, dry winters, average rainfall of $1221 \mathrm{~mm}$, with the coldest month temperature below $18^{\circ} \mathrm{C}$ and above $3^{\circ} \mathrm{C}$ and temperature of the hottest month exceeding $22^{\circ} \mathrm{C}$ (Arruda et al., 1999).

The topography of the area is rugged with narrow, humid valleys. The region has strong undulating and mountainous terrain and coincidence of elevations tops, with dominance of concave-convex profile slopes. The region is presented geologically grounded in gneiss-granite substrate, with three classes of predominant soils: dystrophic Yellow Oxisol in the convex tops and Red-Yellow Oxisol on the slopes of elevations; Red-Yellow Cambic Ultisol in the terraces; and at the back of the valleys, where are found the larger beds, Fluvisols associated with the hydromorphic ones (Rezende et al., 1972).

An accidental fire culminated with the destruction of 12 hectares of native vegetation, showing differential levels of degradation. At 14 months after the fire, it was held a survey of all the species that showed regrowth. The study concentrated on the stretch where the effect of fire was more drastic, with total destruction of the vegetation cover. It was measured the diameter $(\mathrm{cm})$ at the base of the bud, using a caliper, and its height $(\mathrm{m})$, with the aid of a measuring tape. Botanical material was collected for taxonomic identification of species. It were also performed measures of distance between the originating shoots and the mother plant.

The finding and identification of species, which were established based on the regrowth of strains, were conducted examining, in each individual, the inclusion of shoots in the stem base. As for species with regrowth of bud roots, were carried out excavations and exposure of the root system starting from the base of stem of the sprouts issued, in order to confirm their connection to the trunks of adult individuals (Penha et al., 2002) that were hit by fire.

\section{Results and discussions}

Individuals who resprouted from stems and roots after the fire contributed to the recovery of species richness, as they showed size for inclusion in the tree layer (Figure 1). It appears that the species Aegiphila sellowiana, Dalbergia nigra and Mabea fistulifera contributed with $59 \%$ of all shoots, what shows a high capacity for regrowth of these individuals. The species in the group "other" (totaling 12) accounted for only $11 \%$ of the total shoots, each of which contributes with less than $3 \%$ of this total and 8 of them represent less than $1 \%$. A similar result was recorded 
by Melo \& Durigan (2010) in a Semideciduous Forest, especially in relation to Piptadenia gonoacantra and Dalbergia nigra species belonging to the family of Leguminosae. This may indicate that this family has a greater capacity for regrowth in environments that suf- fered burnings, since in these two studies, about $25 \%$ of the species that more showed sprouting belong to this family, or even because this family would be most abundant in the area before the burning.

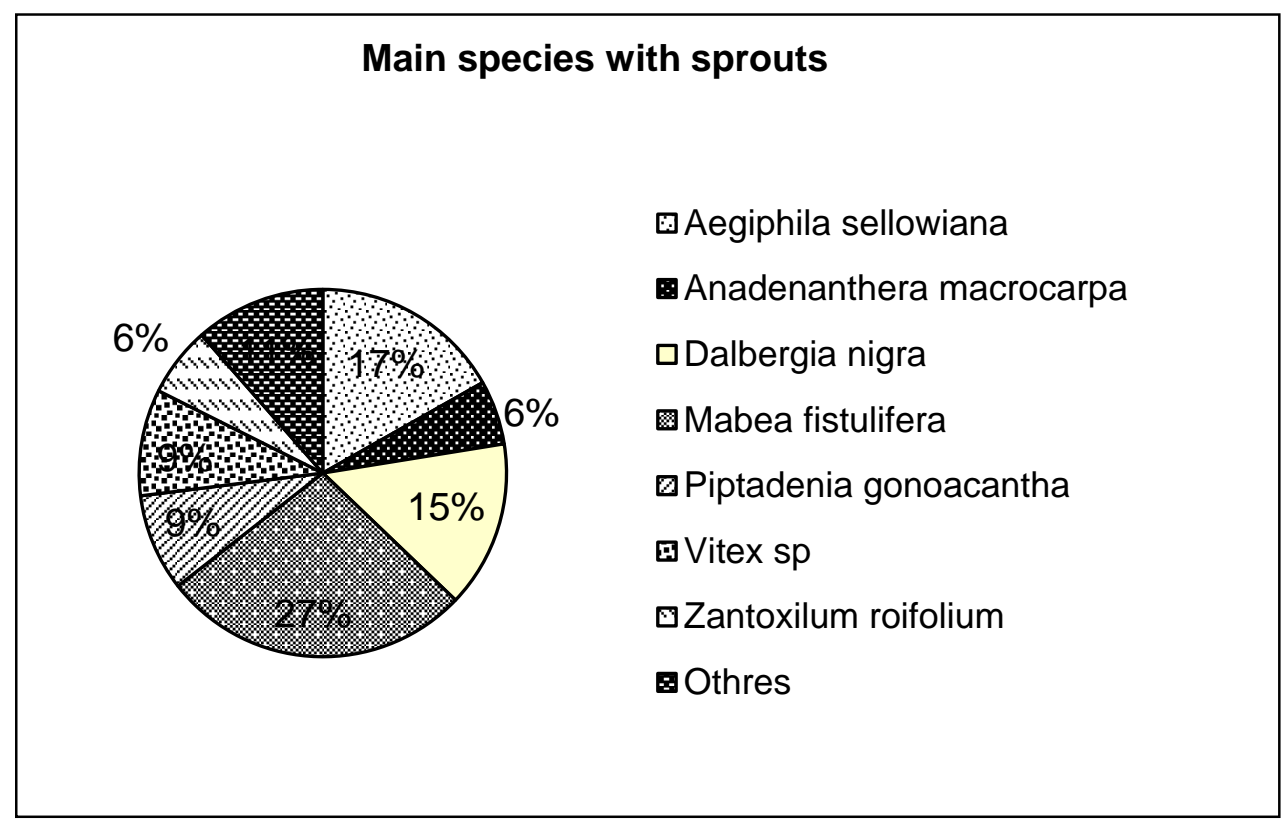

Figure 1 - Percentage distribution of sprouting among species in the study area.

The difference in the regrowth capacity may be due to the number of arrays, low regrowth capacity, the degree of injury caused, the specific potential of each species or even by other factors such as competition and adaptation to the degraded environment (Silva et al., 2005). Regeneration by regrowth of tree species post-fire occurs initially with low density, being more important for pioneer species, giving them an opportunity of quick occupation of the disturbed environment (Uhl et al., 1981).

In some species as Myrcia fallax and Luehea grandiflora it was found only an array with one bud each, while Mabea fistulifera, of the family Euphorbiaceae, and Dalbergia nigra, family Fabaceae, had 74 and 22 arrays with regrowth, respectively, what indicates a high potential for regrowth of these species. Highest average of shoots per array were observed in Anadenanthera macrocarpa (7.0 shoots), Aegiphila sellowiana (6.67 shoots) and Peltophorum dubium (6.0 shoots).

About $80 \%$ of the species showed shoots with a height superior than $1 \mathrm{~m}$. Notwithstanding, the standard deviation of the height of shoots showed a high value $(0.71 \mathrm{~m})$ in relation to the average height $(1.45 \mathrm{~m})$, demonstrating the wide variation found for this feature, probably by the difference in the rate of emission of shoots, growth of species and higher fire-resistance capacity of the arrays (Table 1).

Peltophorum dubium (Spreng.) Taub, with only one array, showed shoots with larger diameter, followed by Anadenanthera macrocarpa (Benth.) Brenan, with five arrays. On the other hand,
Anadenanthera macrocarpa and Piptadenia gonoacantha present, besides large diameter, the largest heights of shoots, demonstrating therefore high capacity for regrowth and growth rate that impart them a greater importance in the recovery process of these areas.

In only four species it was verified budding by roots (Table 2), and only two of them (Machaerium triste and Zanthoxylum rhoifolium) scored. As the fire was quickly controlled, it could be assumed that the heat produced may not have reached enough depth to trigger the gems of the roots, explaining the low incidence found for this type of regrowth. It is further believed that the aggressive presence of the molasses grass (Melinus minutiflora), recorded by Martins et al. (2002), soon after the occurrence of the fire in this area, and by Silva et al. (2005), in a similar forest, might have represented a physical impediment and light reduction to the initial development of root sprouts.

Normally, with the destruction of the shrub-tree vegetation by fire, the grass species are favored due to the increase in light levels that stimulate tillering (Silva et al., 2005; Castellani \& Stubblebine, 1993) and by the increased availability of nutrients (Coutinho, 1990; Martins et al., 1995). The aggressiveness of these species can inhibit the regeneration of later species in plant succession (Zahawi \& Augspurger, 1999). For D'Antonio et al. (2000), these invasive communities, when very aggressive, can intensify the competition for resources and, following an inhibition model, delay the regeneration process. 
Table 1 - Number of arrays per species (Arrays), average number of shoots per array (Shoots), average height of seedlings (Height) and average diameter at the base of the shoots (Diameter) of the species found in the study area.

\begin{tabular}{lcccc}
\hline Species & Arrays & Shoots & $\begin{array}{c}\text { Height } \\
(\mathrm{m})\end{array}$ & $\begin{array}{c}\text { Diameter } \\
(\mathrm{cm})\end{array}$ \\
\hline Aegiphila sellowiana Cham. & 15 & 6.67 & 1.33 & 1.69 \\
Anadenanthera macrocarpa (Benth.) Brenan & 5 & 7.00 & 2.28 & 2.83 \\
Apuleia leiocarpa (Vogel) J.F. Macbr. & 1 & 4.00 & 2.03 & 2.43 \\
Casearia sp & 1 & 3.00 & 1.70 & 1.23 \\
Dalbergia nigra (Vell.) Alemão ex. Benth. & 22 & 3.82 & 1.38 & 1.41 \\
Dictyoloma sp & 2 & 2.50 & 1.32 & 1.78 \\
Erythroxylum sp & 2 & 2.50 & 1.32 & 1.78 \\
Jacaranda macrantha Cham. & 3 & 3.00 & 0.80 & 1.11 \\
Luehea grandiflora Mart. & 1 & 1.00 & 1.50 & 1.70 \\
Mabea fistulifera Mart. & 74 & 2.80 & 0.77 & 0.80 \\
Machaerium triste Vogel & 4 & 4.00 & 1.28 & 1.58 \\
Myrcia fallax (Rich.) DC. & 1 & 1.00 & 1.40 & 1.10 \\
Piptadenia gonoacantha (Mart.) J.F. Macbr. & 11 & 4.81 & 2.33 & 2.66 \\
Peltophorum dubium & 1 & 6.00 & 1.77 & 3.33 \\
Piptocarpha sp & 1 & 4.00 & 0.83 & 0.90 \\
Plathypodium elegans Vogel & 3 & 3.67 & 1.62 & 1.69 \\
Unknown & 2 & 5.00 & 0.56 & 0.62 \\
Vitex sp & 15 & 3.87 & 1.64 & 1.65 \\
Zanthoxylum rhoifolium Lam. & 11 & 3.45 & 1.69 & 1.68 \\
\hline Mean & 9.16 & 3.72 & 1.45 & 1.68 \\
Standard deviation & 16.89 & 1.72 & 0.71 & 0.99 \\
\hline
\end{tabular}

Table 2 - Number of shoots arising from roots and average distance of the shoot relative to the mother plant found in the study area.

\begin{tabular}{lcc}
\hline Species & Total of shoots & Average distance of the shoot $(\mathrm{m})$ \\
\hline Aegiphila sellowiana & 43 & 2.14 \\
Mabea fistulifera & 12 & 1.31 \\
Machaerium triste & 1 & 0.4 \\
Zanthoxylum rhoifolium & 1 & 0.1 \\
\hline Mean & & 1.90 \\
Standard deviation & & 2.48 \\
\hline
\end{tabular}

The distance between the shoot and the plant mother varied greatly, being found mean values in the range of 0.1 to $2.14 \mathrm{~m}$ (Table 2). The species with shoots more distant from the array was Aegiphila sellowiana, probably by the presence of a shallow root system, developed laterally, which enabled a larger storage of organic and inorganic reserves, or even because the species has distinctive characteristics for this type of sprouting. There was an increase in the number of shoots issued in relation to the increase of the distance from the main trunk to Aegiphila sellowiana and Mabea fistulifera.

It is highlighted the difference observed between the diameter at the base and the height of the shoots by root and stem. The sproutings by roots showed a diameter and height of $1.40 \mathrm{~cm}$ and $1.01 \mathrm{~m}$, respectively, while in the sproutings by stem, the average values of diameter $(1.82 \mathrm{~cm})$ and height $(1.64 \mathrm{~m})$ were higher.

Figure 2 shows the relationship between root shoots and stem shoots in the species with the two types of shoots. It was found that for Aegiphila sellowiana, the relationship stem/root sprouting was low, which may highlight the importance of sprouting by roots in the survival of this species in areas of occurrence of fire and/or for recovering of the same. For the other species, which have shown the two types of sprouting, this relationship has performed high, not being representative, in these, the sprouting by roots (Figure 2). Nonetheless, in these species, the regrowth 
from the stem may indicate another restoration standard of the tree community in the fragment, parallel to that of the pioneer species. Castellani \&
Stubblebine (1993) also observed regrowth from the stem for the Zanthoxylum rhoifolium species.

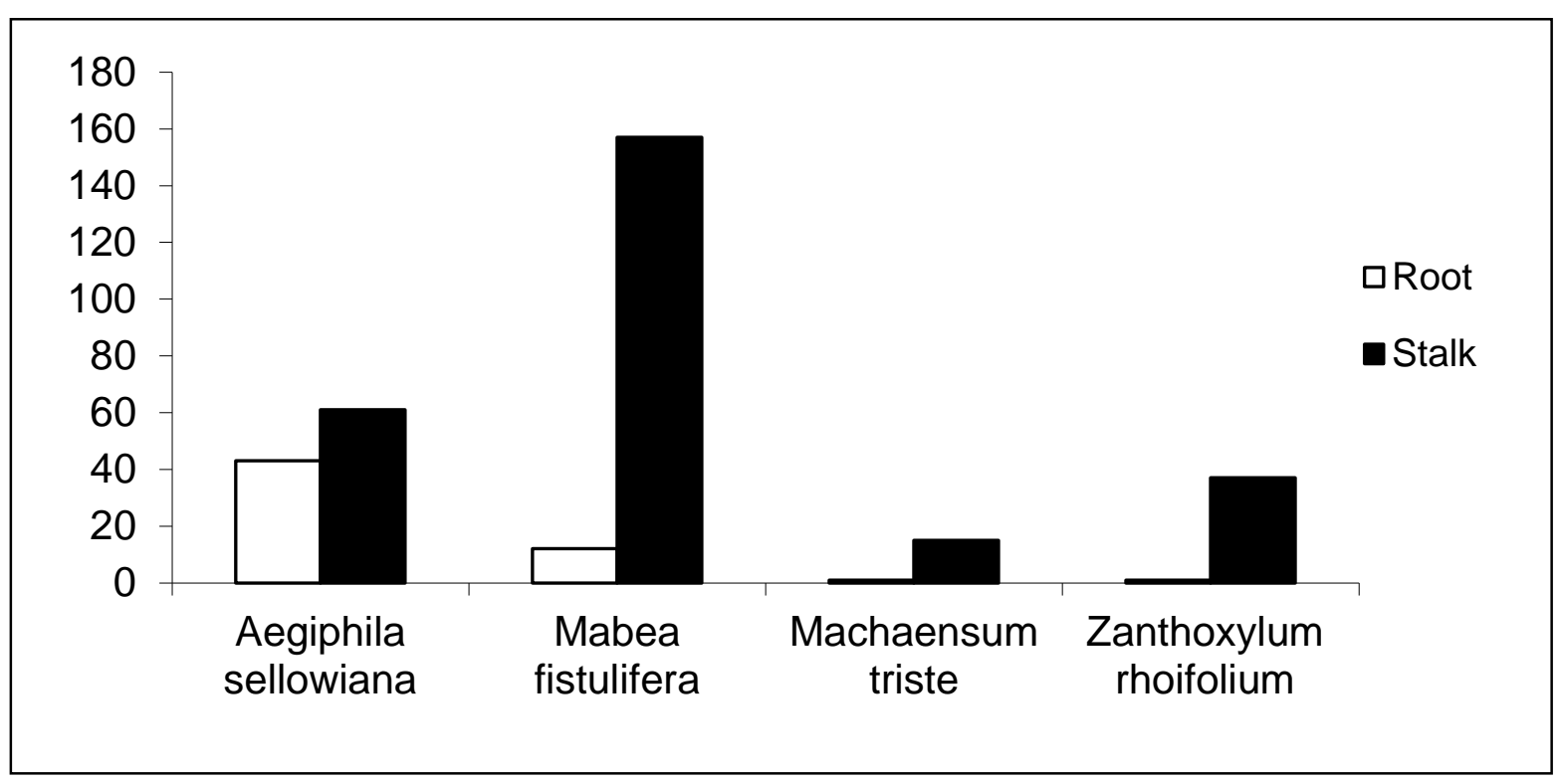

Figure 2 - Number of root shoots and stem shoots in species with the two types of sproutings.

\section{Conclusions}

The species Mabea fistulifera, Aegiphila sellowiana and Dalbergia nigra had higher number of individuals with shoots and greater capabilities of regrowth after fire.

The species Aegiphila sellowiana, Mabea fistulifera, Manchaerium triste and Zanthoxylum rhoifolium showed regrowth by root and stem.

The molasses grass (Melinis minutiflora) represented a physical impediment and light reduction for shoots by roots.

\section{References}

Arruda PRR, Silva E, Couto L (1999) Problemática ambiental da bacia hidrográfica do Ribeirão São Bartolomeu, Viçosa-MG. Revista Árvore 23(1):49-53.

Castellani TT, Stubblebine WH (1993) Sucessão secundaria em mata tropical mesófila após perturbação por fogo. Revista Brasileira de Botânica 16(2):181-203.

Cochrane M, Schulze MD (1999) Fire as a recurrent event in tropical forests of the eastern Amazon: effects on forest structure, biomass, and species composition. Biotropica 31(1):2-16.

Coutinho LM (1990) O Cerrado e a ecologia do fogo. Ciência Hoje 12(1):131-138.

D'Antonio CM, Tunison JT, Loh RK (2000) Variation in the impact of exotic grasses on native plant composition in relation to fire across an elevation gradient in Hawaii. Australian Ecology of Soil Research 25(4):507-522.
Greig N (1993) Regeneration mode in neotropical Piper: habitat and species comparisons. Ecology 74 (7):2125-2135.

Hayashi AH, Penha AS, Rodrigues RR, AppezzatoDa-Gloria B (2001) Anatomical studies of shoot budforming roots of brazilian tree species. Australian Journal of Botany 49(6):745-751.

Hoffmann WA, Solbrig OT (2003) The role of topkill in the differential response of savanna woody species to fire. Forest Ecology and Management 180(1-3):273286.

Hubbell SP, Foster RB, O'brien ST, Harns KE, Condit R, Wechsler B, Wright SJ, Loo-De-Lao S. (1999) Lightgap disturbance, recruitment limitation, and tree diversity in a neotropical forest. Science 283:554-557.

Kammesheidt $L$ (1999) Forest recovery by root suckers and above-ground sprouts after slash-and-burn agriculture, fire and logging in Paraguay and Venezuela. Journal of Tropical Ecology 15(2):143-157.

Keeley JE, Lubin D, Fotheringham CJ (2003) Fire and grazing impacts on plant diversity and alien plant invasions in the southern Sierra Nevada. Ecological Applications 13:1355-1374.

Kennard DK, Gould K, Putz FE, Fredericksen TS, Morales F (2002) Effects of disturbance intensity on regeneration mechanisms in a tropical dry forest. Forest Ecology and Management 162:197-208.

Kramer PJ, Kozlowski TT (1972) Fisiologia das árvores. Lisboa: Fundação Calourte Gulbenkian, 745p.

Laurance WF (2003) Slow burn: the insidious effects of 
surface fires on tropical forests. Trends in Ecology and Evolution 18:209-212.

Martins SV, Ribeiro GA, Silva Junior W M, Nappo ME (2002). Regeneração pós-fogo em um fragmento de Floresta Estacional Semidecidual no município de Viçosa, MG. Ciência Florestal 12(1):11-19.

Martins SV, Barros NF, Sampaio OB, Gomes RT (1995) Liberação e lixiviação de nutrientes pela queima da manta orgânica de três coberturas vegetais. Revista Árvore 19(2):149-156.

Melo ACG, Durigan G (2010) Impacto do fogo e dinâmica da regeneração da comunidade vegetal em borda de floresta estacional semidecidual (Gália, SP). Revista Brasileira de Botânica 33(1):37-50.

Otterstrom SM, Schwartz MW (2006) Responses to fire in selected tropical dry forest trees. Biotropica 38:592-598.

Penha AS, Rodrigues RR, Hayashi AH, Appezato-DaGlória B (2002) Tree species sprouting from buds in a tropical forest community affected by fires in Southeast Brazil. Brazilian Archives of Biology and Technology 47:127-133.

Rezende SB, Resende M, Galloway HM (1972) CronoTopossequência de Solos em Viçosa, MG. Revista Ceres 19:167-181.

Rodrigues RR, Martins SV, Matthes LHF (2005) Postfire regeneration in a semideciduous mesophytic forest, south-eastern Brazil.. In: Burk AR (ed.) New research on forest ecosystems. Nova Science Publishers, p.1-19
Rodrigues RR, Torres RB, Matthes LAF, Penha AF (2004) Trees species resprouting from root buds in a semideciduous forest affected by fires, Campinas, southeast Brazil. Brazilian Archives of Biology and Technology 47(1):127-133.

Sharma RP (1979) Production potential and other crop characters of the first generation coppice of Eucalyptus hybrid. Indian Forester 105(2):89-100.

Silva VF, Oliveira Filho AT, Venturin N, Carvalho WAC, Gomes JBV (2005) Impacto do fogo no componente arbóreo de uma floresta estacional semidecídua no município de lbituruna, MG, Brasil. Acta Botânica Brasilica 19(4):701-716.

Sheil D, Burslem DFRP (2003) Disturbing hypotheses in tropical forests. Trends in Ecology and Evolution 18:18-26.

Uhl C, Clark K, Clark H, Murfhy P (1981) Early plant succession after cutting and burning in the upper Rio Negro region of the Amazon Basin. Journal of Ecology 69(2):631-649.

Woods P (1989) Effects of logging, drought and fire on structure and composition of forests in Sabah, Malaysia. Biotropica 21:290-298.

Zahawi RA, Augspurger CK (1999) Early plant succession in abandoned pastures in Ecuador. Biotropica 31(4):540-552. 